ReVISTA de BIOLOGía TROPICAL

\title{
Population structure and reproductive biology of Astyanax gymnodontus (Characiformes: Characidae), a poorly known endemic fish of the Iguaçu River basin, Brazil
}

\author{
Matheus Tenório Baumgartner ${ }^{1}$, Pedro Rogério Leandro da Silva ${ }^{2} \&$ Gilmar Baumgartner ${ }^{3}$ \\ 1. Universidade Estadual de Maringá (UEM), Departamento de Biologia (DBI), Programa de Pós-Graduação em \\ Ecologia de Ambientes Aquáticos Continentais (PEA), Av. Colombo, 5790, CEP 87020-900, Maringá, Paraná, Brazil; \\ matheus_tbs@hotmail.com \\ 2. Instituto Neotropical de Pesquisas Ambientais (INEO). Rua Guaíra, 2006, CEP 85902-140, Toledo, Paraná, Brazil; \\ pedropesca@yahoo.com.br \\ 3. Universidade Estadual do Oeste do Paraná (UNIOESTE), Centro de Ciências Exatas (CECE), Grupo de Pesquisas \\ em Recursos Pesqueiros e Limnologia (GERPEL), Rua da Faculdade, 645, CEP 85903-000, Toledo, Paraná, Brazil; \\ gilmar_baum@yahoo.com.br
}

\section{Received 11-II-2015. Corrected 20-VII-2015. Accepted 25-VIII-2015.}

\begin{abstract}
Success in fish breeding depends on reproduction intensity, periodicity and the place where it occurs. Information about fish species reproduction is important to assist managers, and to determine conservation and management strategies. The fish assemblage of the Iguaçu River basin is already known for its high endemism, and despite this privilege, the large number of dams built along it, threat this particular biodiversity. Astyanax gymnodontus is an endemic fish species and studies on its population structure and reproductive biology are important, since they represent the first step for further community studies. Our objective was to evaluate some aspects of the population structure and reproductive biology of A. gymnodontus in the influence area of Salto Santiago dam, Iguaçu River, Paraná State, Brazil. Sampling was made monthly from July 2003 to June 2005, and bimonthly from July 2005 to March 2013, at five sites in the influence area of Salto Santiago dam. Fishes were collected using $10 \mathrm{~m}$ length gillnets with meshes ranging from 2.5 to $6.0 \mathrm{~cm}$ between non-adjacent knots and trammel nets with inner meshes of $6.0 \mathrm{~cm}$ between non-adjacent knots. Nets were arranged on surface, bottom and margins of each site, exposed for $24 \mathrm{~h}$. Additional drags on littoral areas were performed from January to March and October to December from 2009 to 2011, with $50.0 \mathrm{~m}$ nets, $0.5 \mathrm{~cm}$ mesh size, for juveniles capture. We captured and analyzed 21932 individuals, being 9249 females and 12683 males, representing $42.2 \%$ and $57.8 \%$, respectively. The average body length was $8.8 \mathrm{~cm}$ for females and $8.3 \mathrm{~cm}$ for males. The average weight was $18.8 \mathrm{~g}$ for females and $16.0 \mathrm{~g}$ for males. Sex ratio calculated for the entire period was $1.8 \mathrm{males} /$ female. Males were more abundant than females in $73.2 \%$ of samples and significant differences were observed in 35.3 $\%$ of samples. The estimated length at first maturity $\left(\mathrm{SL}_{50}\right)$ was $6.4 \mathrm{~cm}$ for females and $6.2 \mathrm{~cm}$ for males. We suggest that sexual differences in body length and weight, and sex ratio occurred as a result of sexual differences in energy allocation. Females spend more energy on body growth, which means more eggs production and higher fecundity. As an integrated response, males spend more energy on sperm production, in competition with other males, leading to a smaller body size. Differences in estimated $\mathrm{SL}_{50}$ might be an indicator of this sexual difference in energy allocation. The reproduction period was from September to February, with greater intensity at the beginning of this period, and the sites of highest reproductive intensity were those immediate downstream from dams, and therefore with more riverine characteristics. Rev. Biol. Trop. 64 (1): 69-77. Epub 2016 March 01.
\end{abstract}

Key words: reproductive biology, gonadosomatic index, RAI, fish ecology.

One of the major obstacles for biodiversity conservation is the lack of accurate information about the biology of the species, especially on how they occupy the environment and reproduce. According to Wootton (1984), success in fish species breeding depends on when and where it occurs. Therefore, information about population structure and reproductive 
biology of fish species, covering spawning regions and reproductive intensity are important to determine conservation and management strategies.

The Iguaçu River basin is a representative system in South America and 106 fish species are known for this basin (Garavello, Pavanelli, \& Suzuki, 1997; Ingenito, Duboc, \& Abilhoa, 2004; Baumgartner et al., 2006; Baumgartner et al., 2012). However, approximately $70.0 \%$ of these species are endemic, especially those representing the genus Astyanax (Garavello et al., 1997; Alcaraz, Pavanelli, \& Bertaco, 2009). This elevated species endemism, despite being such a privilege, also warn researchers and governors about the importance of preserving this region, since most of the species found there cannot be found anywhere in the planet; this means that local extinctions could turn into global extinctions for most of these species.

Previously known as Astyanax sp. F and Psalidodon gymnodontus, Pavanelli and Oliveira (2009) gathered these two species in a single one called Astyanax gymnodontus (Eigenmann, 1911). For this species, literature reports that it feeds primarily on terrestrial insects, also eating plants and other fish (Hahn, Fugi, Almeida, Russo, \& Loureiro, 1997; Cassemiro, Hahn, \& Delariva, 2005; LoureiroCrippa \& Hahn, 2006). In addition, Suzuki and Agostinho (1997) and Baumgartner et al. (2012) provide some aspects of its reproductive activity. Thereby, the present study uses an extensive database to provide additional information on this species reproductive biology.

Thus, this study evaluated some aspects of population structure (average and maximum individual length and weight, and sex ratio) and some aspects of reproductive biology as length at first maturity, reproduction period, and sites of higher reproduction intensity of A. gymnodontus, in the influence area of Salto Santiago dam, Iguaçu River, Paraná State, Brazil.

\section{MATERIAL AND METHODS}

Study area: The reservoir of Salto Santiago is located in the Iguaçu River, near the city of Saudade do Iguaçu, $370 \mathrm{~km}$ from its confluence with the Paraná River. It drains approximately $43330 \mathrm{~km}^{2}$ and floods an area of $208 \mathrm{~km}^{2}$ (Tractebel Energia, \& Ecsa, 2002). Third in the series of five large reservoirs built within this river, its operation by accumulation very often results in water level variation up to $25.0 \mathrm{~m}$ on periods of more or less precipitation, regardless of seasonality.

Sampling: Samples were conducted monthly from July 2003 to June 2005, and bimonthly from July 2005 to March 2013, in one site located downstream (JUS $=$ Jusante $25^{\circ} 37^{\prime} 41^{\prime \prime} \mathrm{S}-52^{\circ} 37^{\prime} 11^{\prime \prime} \mathrm{W}$ ), and four sites located upstream $(\mathrm{BAR}=$ Barragem $25^{\circ} 35^{\prime} 03^{\prime}$ ' S-52 $34^{\prime} 52^{\prime \prime}$ W; POS = Porto Santana $25^{\circ} 40^{\prime} 05^{\prime \prime} \mathrm{S}-52^{\circ} 28^{\prime} 46^{\prime \prime} \mathrm{W}$; CAV = Cavernoso $25^{\circ} 35^{\prime} 14^{\prime \prime} \mathrm{S}-52^{\circ} 17^{\prime} 52^{\prime \prime} \mathrm{W}$; IAT = Iate $25^{\circ} 44^{\prime} 54^{\prime \prime}$ S - 52 14 '58” W) the Salto Santiago dam (Fig. 1). Fish were collected using $10 \mathrm{~m}$ length gillnets with meshes ranging from 2.5 to $6.0 \mathrm{~cm}$ between non-adjacent knots and trammel nets with inner meshes of $6.0 \mathrm{~cm}$ between non-adjacent knots. Nets were arranged on surface, bottom and margins of each site, exposed for 24 hours. Moreover, additional drags were performed from January to March, and October to December from 2009 to 2011, with $50.0 \mathrm{~m}$ nets, $0.5 \mathrm{~cm}$ mesh size, for juveniles capture.

Laboratory analysis: Fish were stored on ice and transported to the laboratory. They were identified according to Garavello et al. (1997), Reis, Kullander, and Ferraris Junior (2003), Graça and Pavanelli (2007) and Baumgartner et al. (2012), and exemplars were stored at the Grupo de Pesquisas em Recursos Pesqueiros e Limnologia - Gerpel fish collection (CIG-1259, CIG-1394 CIG-1395, CIG-1808). Measurements of total (TL) and standard (SL) length, weight $(\mathrm{Wt})$, sex, stage of gonadal maturity and gonad weight $(\mathrm{Wg})$ were taken. Sex and gonadal maturity classification were made according to macroscopic inspection of gonads evaluating: vascularization pattern, organ consistency, relative occupancy of the abdominal cavity, size and possibility of viewing the 


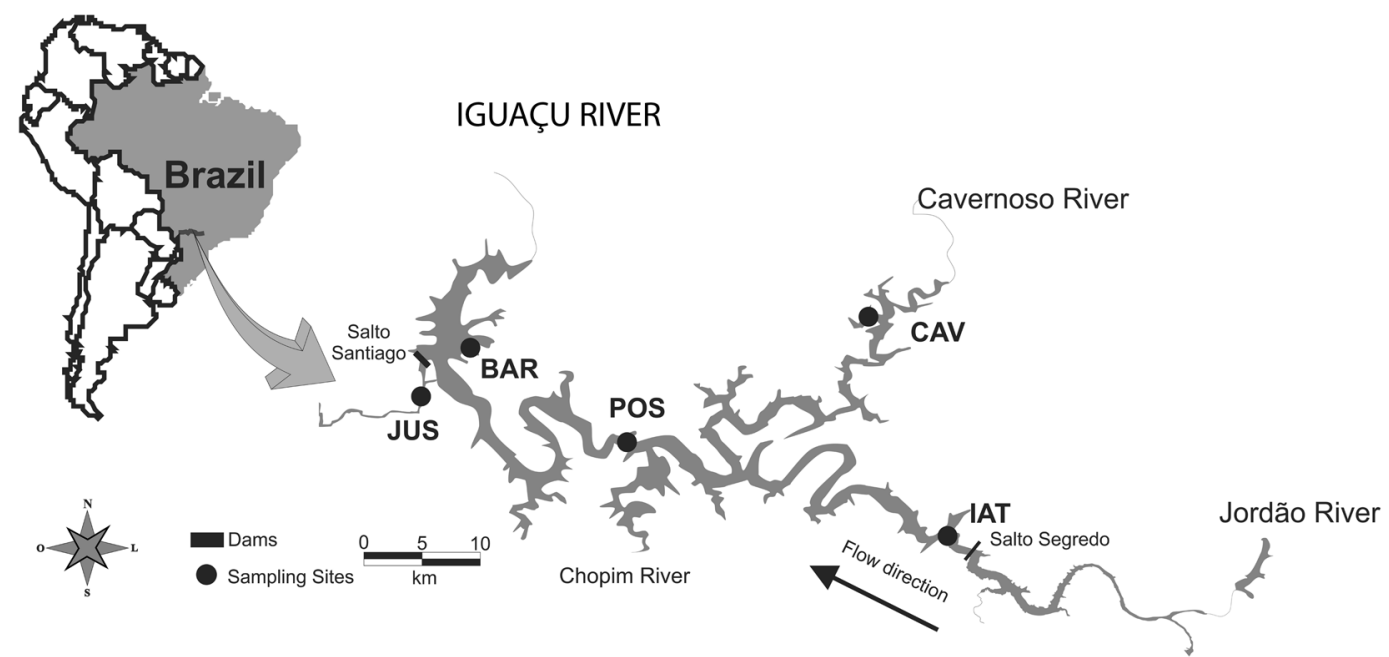

Fig. 1. Sampling sites and the Salto Santiago dam position, Iguaçu River, Paraná, Brazil (JUS = Jusante 2537'41" S -

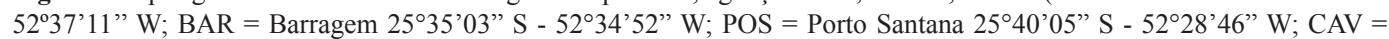
Cavernoso $25^{\circ} 35^{\prime} 14^{\prime \prime} \mathrm{S}-52^{\circ} 17^{\prime} 52^{\prime \prime}$ W; IAT = Iate $25^{\circ} 44^{\prime} 54^{\prime \prime} \mathrm{S}-52^{\circ} 14^{\prime} 58^{\prime \prime} \mathrm{W}$ ).

oocytes (in the case of the ovaries). Therefore, the following classes were assigned: Imt = immature or young; Mat = developing; Mad $=$ able to spawn; Esg = regressing; Reg = regenerating (Vazzoler, 1996; Brown-Peterson, Wyanski, Saborido-Rey, Macewicz, \& Lowerre-Barbieri, 2011).

Data Analysis: Average and maximum body length and weight were calculated from original data. The Kolmogorov-Smirnov test was applied to assess differences in the distribution of individuals within length classes. The sex ratio was calculated for each sample and for the entire period. Differences in sex ratio were assessed using the log-likelihood ratio ( $G$ test).

The lengths at first maturity $\left(\mathrm{SL}_{50}\right)$, at which $50.0 \%$ of individuals are able to breed, were estimated using Galton's ogive method (Fonteles-Filho, 1989), using the classification described above, for females and males, separately. Then, an analysis of covariance (ANCOVA) was performed on log-transformed model data to assess whether $\mathrm{SL}_{50}$ was significantly different between sexes.
To calculate the Reproduction Activity Index - RAI (Suzuki \& Agostinho, 1997) the following equations were used:

$$
\begin{aligned}
& G S R=\left(\frac{w_{g}}{w_{t}-w_{g}}\right) * 1000 \\
& R A I=\frac{\ln N_{i}\left(\frac{n_{i}}{\sum n_{i}}+\frac{n_{i}}{N_{i}}\right) *\left(\frac{G S R_{i}}{G S R_{e}}\right)}{\ln N_{m}\left(\frac{n_{m}}{\sum n_{i}}+1\right)} * 100
\end{aligned}
$$

where: $G S R=$ Gonadosomatic Relationship; $w_{g}$ $=$ gonad weight; $w_{t}=$ individual weight; $N_{i}=$ number of females in sampling unit $i ; n_{i}=$ number of females in reproduction in sampling unit $i ; N_{m}=$ number of females in the most numerous sampling unit; $n_{m}=$ number of females in reproduction in the sampling unit with highest $n ; G S R_{i}=$ average Gonadosomatic Relationship of females in reproduction in sampling unit $i ; G S R_{e}=$ highest individual value of GSR for females.

RAI values were calculated for each site within each month to determine whether reproduction occurred at higher intensity, considering $(\mathrm{RAI} \leq 5$ : incipient; $5 \leq \mathrm{RAI} \leq 10$ : moderate; $10 \leq \mathrm{RAI} \leq 20$ : intense; $20<\mathrm{RAI}$ : 
very intense, Suzuki \& Agostinho, 1997). The use of only females to calculate RAI, which considers the relationship between body and ovary weights, follows the argument of Wootton (1990), which states that testicles size may vary according to the proximity between male and female at the time of spawning, which allows us to identify a trend in getting an underestimated measure males RAI. To determine the reproduction period, the RAI values were plotted for each cycle (considered from July to June), and then observed when these values were usually higher. To determine the sites of greatest reproduction intensity, RAI values obtained for the months of the reproduction period were grouped according to sites and univariate analysis of variance (ANOVA) was performed. For all analyzes we used $\mathrm{R}$ software, version 3.0.3., in the usual form ( $R$ Core Team, 2014).

\section{RESULTS}

For the entire sampling we captured 21932 individuals, with 9249 females and 12683 males, representing $42.2 \%$ and $57.8 \%$, respectively. For females, the maximum length was $21.0 \mathrm{~cm}$ and the average was $8.8 \mathrm{~cm}$, while males had their maximum at $15.0 \mathrm{~cm}$ and the average was $8.3 \mathrm{~cm}$. The maximum weight for females was $190.0 \mathrm{~g}$ and the average weight was $18.8 \mathrm{~g}$, while the maximum weight for males was $94.4 \mathrm{~g}$ and the average weight was $16.0 \mathrm{~g}$.

The Kolmogorov-Smirnov test was significant for both females $(D=0.44, \mathrm{P}<0.05)$ and males $(D=0.46, \mathrm{P}<0.05)$, indicating differences in the distribution of individuals within length classes. Males were clearly more abundant in smaller length classes, but as body size rises, there is a clear trend of higher abundance of females (Fig. 2).

The sex ratio resulted in a higher number of males in $73.2 \%$ of samples, with an average proportion of 1.8 male/female (Fig. 3). The $G$ test was significant for $35.3 \%$ of samples $(G>3.84, \mathrm{P}<0.05)$, of which in $33.6 \%$ of samples the number of males was higher that of females.

The models obtained from Galton's ogive method resulted in values of $a=6.8 \times 10^{-7}$ and $b=7.4826$ for females and $a=6.41 \times 10^{-6}$ and $b=6.3483$ for males (Fig. 4). The ANCOVA applied to log-transformed axis values of the models was significant $(F=17.16, \mathrm{P}<0.01)$, leading to the estimation of the length at first

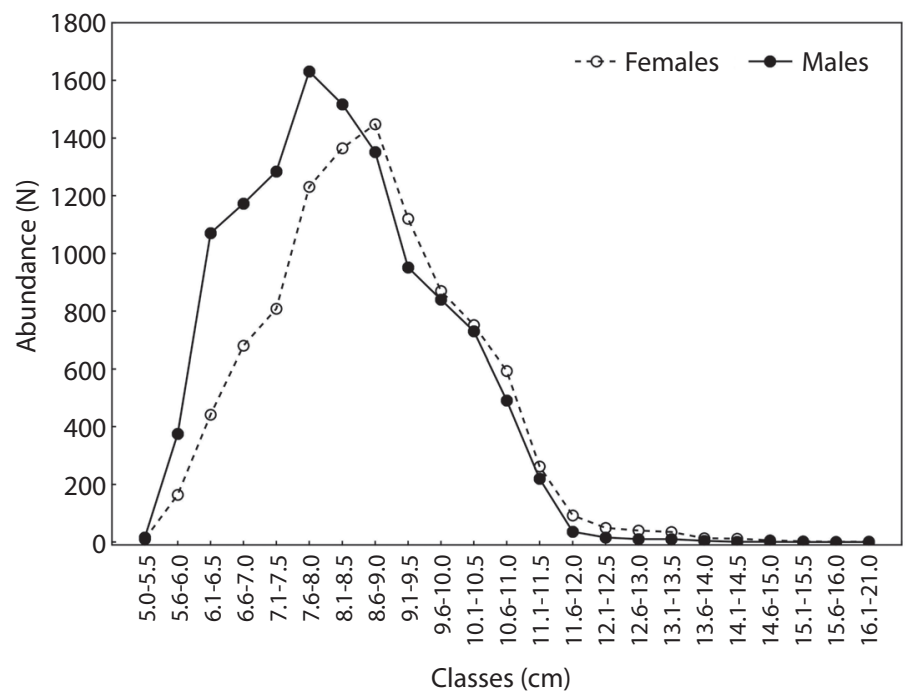

Fig. 2. Number of females and males of Astyanax gymnodontus from 2003 to 2013, grouped by size classes of standard length (SL), in the influence area of Salto Santiago dam, Iguaçu River, Paraná, Brazil. 


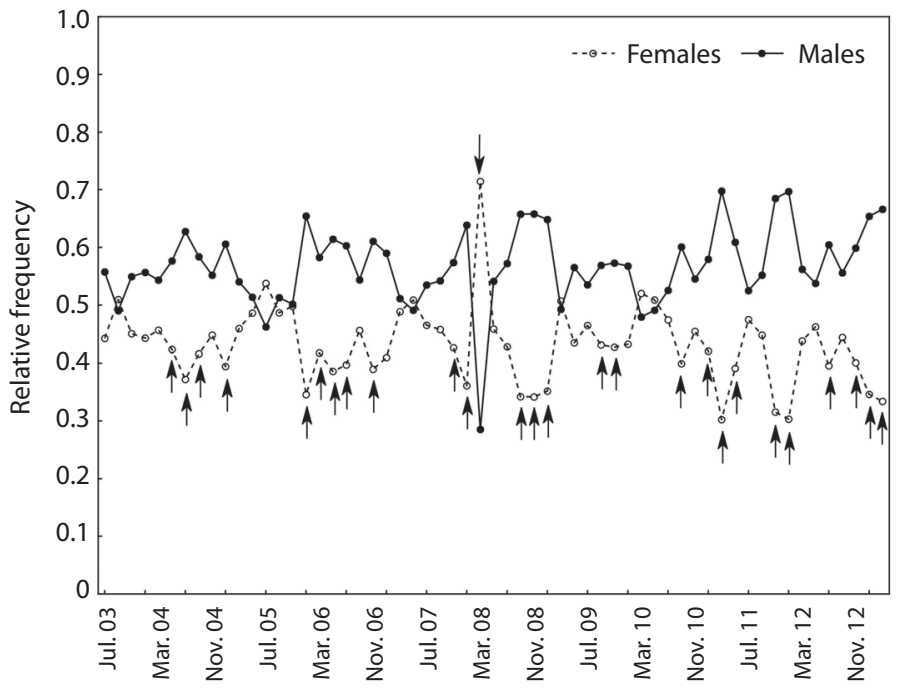

Fig. 3. Relative frequency of females and males of Astyanax gymnodontus from 2003 to 2013, in the influence area of Salto Santiago dam, Iguaçu River, Paraná, Brazil. The arrows indicate samplings that sex ratio was significantly different from 1:1.
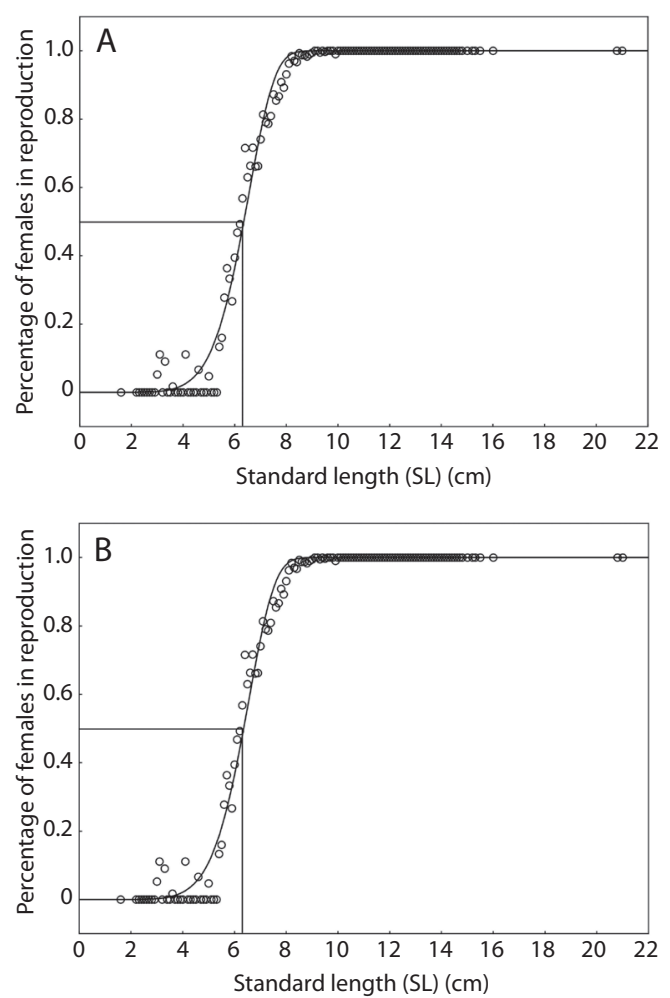

Fig. 4. Estimated length at first maturity $\left(\mathrm{SL}_{50}\right)$ obtained from the Galton's ogive method for females $(\mathrm{A})$ and males (B), from the population of Astyanax gymnodontus from 2003 to 2013, in the influence area of Salto Santiago dam, Iguaçu River, Paraná, Brazil. 
maturity $\left(\mathrm{SL}_{50}\right)$ of $6.4 \mathrm{~cm}$ for females and 6.2 $\mathrm{cm}$ for males.

The highest RAI values were registered in November for all reproduction cycles in this study, presenting intense or very intense reproduction activity, except for the cycle '0304 that had its highest RAI value in October, and the cycle '06-07 when reproduction was only moderate (Fig. 5). It is possible to observe a strong increase in reproduction activity from already high RAI values in September to even higher in November, and a regular decay after that, until February. Therefore, A. gymnodontus reproduction period was from September to February, with greater intensity at the first half of this period.

Regarding spawning, sites JUS and IAT registered the highest RAI average, classified as intense spawning. The ANOVA applied to RAI values from September to February was significant $(F=3.19, \mathrm{P}=0.015)$ and the posthoc (Fisher's LSD) indicated that sites JUS and IAT had significant higher RAI values. In BAR and CAV the lowest means of RAI were observed, classifying the reproduction activity from incipient to moderate and in POS only from moderate to intense (Fig. 6).

\section{DISCUSSION}

Females with larger body length and weight corroborate the theory that body size is the most frequent sexual dimorphism among fish (Nikolsky, 1963). According to Allen et al. (2006) species body size can be influenced by a variety of energetic, evolutionary, biogeographic and ecosystem processes. Shine (1990) claims that this sexual dimorphism is influenced by population's genetic pool and environmental conditions, and it is extremely difficult to assess which combination of factors is driving these differences with greater intensity. For fish, usually abiotic conditions (especially dissolved oxygen and water temperature), physical space and food availability, and biotic interactions are the most important factors that drive body size.

Besides, differences in sex ratio, with the number of males larger than of females was evidenced as a pattern for this species in this stretch of the Iguaçu River. Our observations allowed us to suggest that these differences in body size probably are consequences of different energy allocation between sexes. Females probably spend more energy on body growth

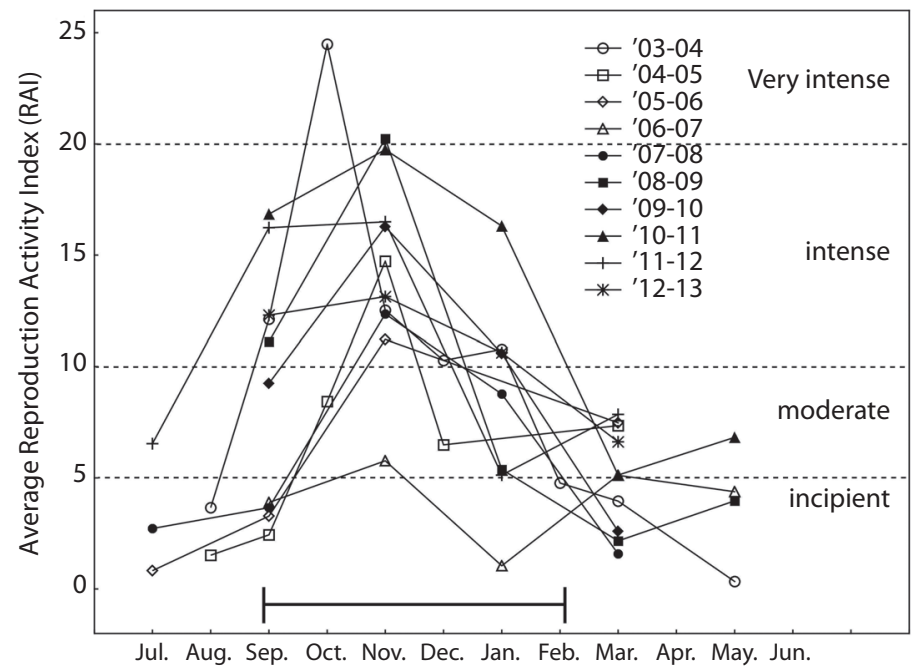

Fig. 5. Mean values of the Reproduction Activity Index (RAI) of females of Astyanax gymnodontus in the influence area of the Salto Santiago dam, Iguaçu River, Paraná, Brazil. The dotted lines represent the thresholds between each reproduction intensity categories and the horizontal bar represents the reproduction period determined for A. gymnodontus. 


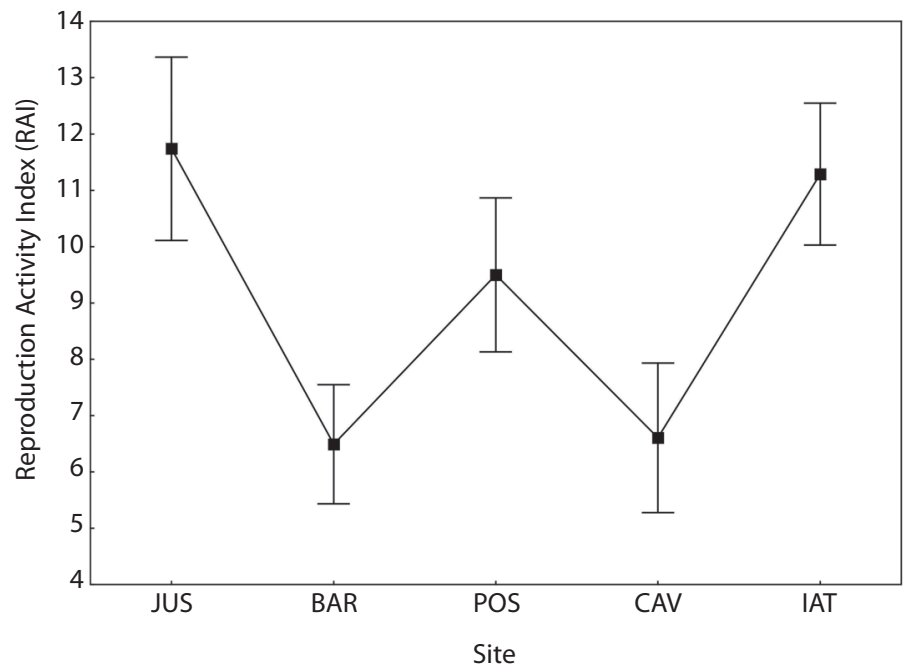

Fig. 6. Mean and standard error of the Reproduction Activity Index (RAI) of Astyanax gymnodontus females, from 2003 to 2013, grouped by site, in the influence area of the Salto Santiago dam, Iguaçu River, Paraná, Brazil.

than males. In this case, larger body means more eggs production and higher fecundity (Morita et al., 1999). On the other hand, males probably spend more energy producing more sperm, in reproductive competition with other males, rather than on growth, as stated by Parker (1982).

We suggest that, as population dynamics, females with larger body produces more eggs and need more sperm for complete fertilization, and males, due to competition with other males of the same species, produce more sperm, leading to smaller body size, although adequate evidence from our data for this conclusion is not available.

On the Iguaçu River basin, 14 valid species of Astyanax (popularly known as "lambari") occur. Specifically on the stretch comprising the influence area of Salto Santiago dam, at least nine species occur (Baumgartner et al., 2012). The most abundant are A. altiparanae, A. bifasciatus, A. dissimilis, A. gymnodontus and $A$. minor, and it was observed that they form mixed shoals, which gives several advantages (for more details see Pavlov \& Kasumyan, 2000). Mise, Fugi, Pagotto, and Goulart (2013) studied three endemic species of Astyanax from the Iguaçu basin and concluded that differences in trophic and morphological attributes allow them to co-occur. Thereby, we suggest that the environmental conditions and ecological processes to which they are submitted are the same for these species. The intensity of these processes turns out to be abundancedependent, and the abundance will depend on biological differences among these congener species. Although methods used were slightly different, in comparison with data provided by Baumgartner et al. (2012), the $\mathrm{SL}_{50}$ estimated in this study for A. gymnodontus was greater than all other Asyanax species, with exception of females of $A$. dissimilis.

The reproduction period observed for $A$. gymnodontus, longer than found by Suzuki \& Agostinho (1997), is probably because their study was conducted right after the reservoir filling. In our case, when studies started, the reservoir had 20 years passed since its filling. The reproduction intensity at the beginning of the period and field observations leads us to suggest that this species has complete spawning, but only additional histological techniques would confirm that.

The sites where reproduction was more intense are located immediate downstream from Salto Segredo and Salto Santiago. Not 
coincidently, these sites share more riverine characteristics, with higher flow velocity, indicating A. gymnodontus preference for sites with these characteristics, as already observed by Suzuki \& Agostinho (1997) for the same species in the Salto Segredo reservoir.

Therefore, our results showed that the sexual differences in energy allocation, which gives advantages in reproduction, is probably the leading cause of differences in body length, weight, and sex ratio, and has directly, influenced the estimated $\mathrm{SL}_{50}$. Thus, our data suggests that this species has intense spawning at the first half of the reproduction period. Sites where reproduction was more intense share more riverine characteristics, indicating preference of the species for sites with these characteristics, although we observed reproductive activity in all sites, showing no directional migration movements to reproduce.

\section{ACKNOWLEDGMENTS}

We thank to Tractebel Energia S. A. for funding, the Grupo de Pesquisas em Recursos Pesqueiros e Limnologia - GERPEL and the Instituto Neotropical de Pesquisas Ambientais - INEO for physical and technical support.

\section{RESUMEN}

Estructura poblacional y biología reproductiva de Astyanax gymnodontus (Characiformes: Characidae), un pez endémico poco conocido de la cuenca del río Iguazú, Brasil. El éxito en la reproducción de los peces depende de su intensidad, cuándo y dónde sucede. La información acerca de la reproducción de las especies de peces son importantes para ayudar a los administradores a determinar las estrategias de conservación y manejo. La comunidad de peces de la cuenca del río Iguazú ya es conocida por su endemismo, y a pesar de ser un privilegio, el gran número de represas construidas en este río amenaza esta biodiversidad particular. Astyanax gymnodontus es una especie endémica de pez y estudios sobre su estructura poblacional y biología reproductiva son importantes, ya que son el primer paso para futuros estudios de comunidad. Nuestro objetivo fue evaluar algunos aspectos de la estructura poblacional y biología reproductiva de $A$. gymnodontus en el área de influencia de la represa de Salto Santiago, Río Iguazú, Estado de Paraná, Brasil. Los muestreos se han realizado mensualmente desde julio 2003 a junio 2005, y cada dos meses desde julio 2005 a marzo 2013, en cinco sitios en el área de influencia del embalse de Salto Santiago. Los peces fueron recolectados con redes de enmalle de $10 \mathrm{~m}$, con mallas entre 2.5 y $6.0 \mathrm{~cm}$ entre nudos no adyacentes y trasmallos con mallas interiores de $6.0 \mathrm{~cm}$ entre nudos no adyacentes. Las redes fueron dispuestas en la superficie, fondo, y márgenes de cada sitio, durante $24 \mathrm{~h}$. Se han usado redes de arrastre adicionales en el litoral de enero a marzo y de octubre a diciembre, desde 2009 a 2011, con redes de $50.0 \mathrm{~m}$ y mallas de $0.5 \mathrm{~cm}$, para la captura de los jóvenes. Hemos capturado y analizado 21932 peces, siendo 9249 hembras y 12683 machos, lo que representa $42.2 \%$ y 57.8 $\%$, respectivamente. La longitud corporal media fue de 8.8 $\mathrm{cm}$ para las hembras y $8.3 \mathrm{~cm}$ para los machos. El peso promedio fue de $18.8 \mathrm{~g}$ para las hembras y $16.0 \mathrm{~g}$ para los machos. La proporción sexual calculada para todo el período fue 1.8 machos/hembra. Los machos fueron más abundantes que las hembras en $73.2 \%$ de las muestras y se observaron diferencias significativas en $35.3 \%$ de las muestras. La longitud corporal de primera madurez $\left(\mathrm{SL}_{50}\right)$ fue de $6.4 \mathrm{~cm}$ para las hembras y $6.2 \mathrm{~cm}$ para los machos. Sugerimos que las diferencias sexuales en la longitud del cuerpo, peso, y proporción sexual se produce como resultado de las diferencias sexuales en la asignación de energía. Las hembras gastan más energía en el crecimiento del cuerpo, lo que significa mayor producción de huevos y mayor fecundidad. Como respuesta, los machos gastan más energía en la producción de esperma, en competencia con otros machos, lo que lleva al menor tamaño corporal. Las diferencias en el $\mathrm{SL}_{50}$ estimado podría ser un indicador de la diferencia sexual en la asignación de la energía. El período de reproducción fue de septiembre a febrero, con mayor intensidad al comienzo de este período, y los sitios de mayor intensidad reproductiva fueron aquellos inmediatamente abajo de los embalses, y por lo tanto, con características más similares a los ríos.

Palabras clave: biología reproductiva, índice gonadosomático, IAR, ecología de peces.

\section{REFERENCES}

Alcaraz, H. S. V., Pavanelli, C. S., \& Bertaco, V. A. (2009). Astyanax jordanensis (Ostariophysi: Characidae), a new species from the rio Iguaçu basin, Paraná, Brazil. Neotropical Ichthyology, 7(2), 185-190.

Allen, C. R., Garmestani, A. S., Havlicek, T. D., Marquet, P. A., Peterson, G. D., Restrepo, C., Stow, C. A., \& Weeks, B. E. (2006). Patterns in body mass distributions: shifting among alternative hypotheses. Ecology Letters, 9, 630-643.

Baumgartner, D., Baumgartner, G., Pavanelli, C. S., Silva, P. R. L., Frana, V. A., Oliveira, L. C., \& Michelon, M. R. (2006). Fish, Salto Osório Reservoir, Iguaçu River basin, Paraná State, Brazil. Check List, 2(1), 1-4. 
Baumgartner, G., Pavanelli, C. S., Baumgartner, D., Bifi, A. G., Debona, T., \& Frana, V. A. (2012). Peixes do baixo rio Iguaçu. Maringá: Eduem.

Brown-Peterson, N. J., Wyanski, D. M., Saborido-Rey, F., Macewicz, B. J., \& Lowerre-Barbieri, S. K. (2011). A standardized terminology for describing reproductive development in fishes. Marine and Coastal Fisheries: Dynamics, Management, and Ecosystem Science, 3(1), 52-70.

Cassemiro, F. A. S., Hahn, N. S., \& Delariva, R. L. (2005). Estrutura trófica da ictiofauna, ao longo do gradiente longitudinal do reservatório de Salto Caxias (rio Iguaçu, Paraná, Brasil), no terceiro ano após o represamento. Acta Scientiarum. Biological Sciences, 7(1), 63-71.

Fonteles-Filho, A. A. (1989). Recursos pesqueiros: biologia e dinâmica populacional. Fortaleza: Imprensa Oficial do Ceará.

Garavello, J. C., Pavanelli, C. S., \& Suzuki, H. I. (1997). Caracterização da Ictiofauna do Rio Iguaçu. In A. A. Agostinho, \& L. C. Gomes (Eds.), Reservatório de Segredo: bases ecológicas para o manejo (pp. 61-84). Maringá: Eduem.

Graça, W. J., \& Pavanelli, C. S. (2007). Peixes da planície de inundação do alto rio Paraná e áreas adjacentes. Maringá: Eduem.

Hahn, N. S., Fugi, R., Almeida, V. L. L., Russo, M. R., \& Loureiro, V. E. (1997). Dieta e atividade alimentar de peixes do reservatório de Segredo. In A. A. Agostinho, \& L. C. Gomes (Eds.), Reservatório de Segredo: bases ecológicas para o manejo (pp. 141-162). Maringá: Eduem.

Ingenito, L. F. S., Duboc, L. F., \& Abilhoa, V. (2004). Contribuição ao conhecimento da ictiofauna da bacia do alto rio Iguaçu, Paraná, Brasil. Arquivos de Ciências Veterinárias e Zoologia da UNIPAR, 7(1), 23-36.

Loureiro-Crippa, V. E., \& Hahn, N. S. (2006). Use of food resources by the fish fauna of a small reservoir (rio Jordão, Brazil) before and shortly after its filling. Neotropical Ichthyology, 4(3), 357-362.

Mise, F. T., Fugi, R., Pagotto, J. P. A., \& Goulart, E. (2013). The coexistence of endemic species of Astyanax (Teleostei: Characidae) is propitiated by ecomorphological and trophic variations. Biota Neotropica, $13(3), 21-28$
Morita, K., Yamamoto, S., Takashima, Y., Matsuishi, T., Kanno, Y., \& Nishimura, K. (1999). Effect on maternal growth on egg and size in wild white-spotted char (Salvelinus luecomaenis). Canadian Journal of Fisheries and Aquatic Siences, 56, 1585-1589.

Nikolsky, G. V. (1963). The Ecology of Fishes. London: Academy Press.

Parker, G. A. (1982). Why are there so many tiny sperm? Sperm competition and the maintenance of two sexes. Journal of Theoretical Biology, 96, 281-294.

Pavanelli, C. S., \& Oliveira, C. A. M. (2009). A redescription of Astyanax gymnodontus (Eigenmann, 1911), new combination, a polymorphic characid fish from the rio Iguaçu basin, Brazil. Neotropical Ichthyology, 7(4), 569-578.

Pavlov, D. S., \& Kasumyan, A. O. (2000). Patterns and mechanisms of schooling behavior in fish: a review. Journal of Ichthyology, 40(2), 163-231.

R Core Team (2014). R: A language and environment for statistical computing. Vienna: R Foundation for Statistical Computing.

Reis, R. E., Kullander, S. O., \& Ferraris Junior, C. J. (2003). Check list of freshwater fishes of South and Central America. Porto Alegre: Edipucrs.

Shine, R. (1990). Proximate determinants of sexual differences in body size. American Naturalist, 135(2), 278-283.

Suzuki, H. I., \& Agostinho, A. A. (1997). Reprodução de peixes do reservatório de Segredo. In A. A. Agostinho, \& L. C. Gomes (Eds.). Reservatório de Segredo: Bases Ecológicas para o Manejo (pp. 163-182). Maringá: Eduem.

Tractebel Energia, \& Ecsa. (2002). Plano de uso e ocupação das águas e entorno do reservatório da usina hidroelétrica Salto Santiago. Curitiba: Instituto Ambiental do Paraná.

Vazzoler, A. E. A. M. (1996). Biologia da Reprodução de Peixes Teleósteos: Teoria e Prática. Maringá: Eduem.

Wootton, R. J. (1984). Introduction: strategies and tactics in fish reproduction. In G. W. Potts, \& R. J. Wootton (Eds.). Fish Reproduction: strategies and tactics (pp. 1-12). London: Academic Press.

Wootton, R. J. (1990). Ecology of teleost fishes. London: Chapman \& Hall. 
